\title{
T-cell dysregulation is associated with disease severity in Parkinson's Disease
}

\author{
Divisha Bhatia ${ }^{1 \dagger}$, Veselin Grozdanov ${ }^{1 \dagger}$, Wolfgang P. Ruf ${ }^{1}$, Jan Kassubek ${ }^{1}$, Albert C. Ludolph ${ }^{1,2}$, \\ Jochen H. Weishaupt ${ }^{1,3}$ and Karin M. Danzer ${ }^{1,2^{*}}$
}

\begin{abstract}
The dysregulation of peripheral immunity in Parkinson's Disease (PD) includes changes in both the relative numbers and gene expression of T cells. The presence of peripheral T-cell abnormalities in PD is well-documented, but less is known about their association to clinical parameters, such as age, age of onset, progression rate or severity of the disease. We took a detailed look at T-cell numbers, gene expression and activation in cross-sectional cohorts of PD patients and age-matched healthy controls by means of flow cytometry and NanoString gene expression assay. We show that the well-pronounced decrease in relative T-cell numbers in PD blood is mostly driven by a decrease of $\mathrm{CD}^{+}{ }^{+}$cytotoxic $\mathrm{T}$ cells and is primarily associated with the severity of the disease. In addition, we demonstrate that the expression of inflammatory genes in T cells from PD patients is also associated with disease severity. PDT cells presented with increased activation upon stimulation with phytohemagglutinin that also correlated with disease severity. In summary, our data suggest that the consequences of disease severity account for the changes in PDT cells, rather than age, age of onset, duration or the disease progression rate.
\end{abstract}

Keywords: Parkinson's Disease, T cells, Disease severity, PHA, Gene expression

\section{Introduction}

Neuroinflammation in Parkinson's Disease (PD) includes the infiltration of $\mathrm{T}$ cells into the diseased CNS, with reactive $\mathrm{T}$ cells surrounding neurons and likely contributing to their demise [1]. Neuroinflammation in the CNS is complemented by well-described immune changes in the periphery, including changes in the absolute and relative numbers of monocytes and lymphocytes and their subsets [2-5], increased activation by inflammatory stimuli $[2,6]$ and the presence of auto-immune components, such as $\mathrm{T}$ cells and antibodies reactive to alpha-synuclein $[7,8]$. Recently, $T$ cells have received special attention due to the discovery that the genetic association of HLA-DR

\footnotetext{
*Correspondence: karin.danzer@dzne.de

†Divisha Bhatia and Veselin Grozdanov have contributed equally to this work

${ }^{1}$ Neurology, University Clinic, University of Ulm, Albert-Einstein-Allee 11, 89081 Ulm, Germany

Full list of author information is available at the end of the article
}

haplotypes with PD $[9,10]$ underlies an increase of T cells reactive to a-synuclein $[8,11]$. Other phenotypic changes of $\mathrm{T}$ cells in PD are also known: reduced absolute lymphocyte counts, decreased absolute and relative counts of total $\mathrm{T}$ cells, decreased absolute and relative counts of $\mathrm{CD} 4+$, and sometimes also CD8+lymphocytes, increased Th1/Th2 and Th17/Treg ratios and increased expression of inflammatory cytokines [5, 12-27]. However, most of these changes are also found during healthy aging, making it difficult to discern the impact of a disease, such as PD, which presents with a very broad range of onset ( $30-90$ years) and variable progression rate. Most studies so far concentrated on disease severity, or disease duration as a proxy of it, without considering the influence of sex and aging. As T-cell characteristics are an easily accessible parameter which can be tracked during the course of disease-modifying therapies, it is important to better understand which features correlate with disease severity and how they are biased by original author(s) and the source, provide a link to the Creative Commons licence, and indicate if changes were made. The images or other third party material in this article are included in the article's Creative Commons licence, unless indicated otherwise in a credit line to the material. If material is not included in the article's Creative Commons licence and your intended use is not permitted by statutory regulation or exceeds the permitted use, you will need to obtain permission directly from the copyright holder. To view a copy of this licence, visit http://creativecommons.org/licenses/by/4.0/. The Creative Commons Public Domain Dedication waiver (http://creativeco mmons.org/publicdomain/zero/1.0/) applies to the data made available in this article, unless otherwise stated in a credit line to the data. 
other clinical parameters, such as sex, age, age at onset and progression rate of the disease. Therefore, we investigated several T-cell features in cross-sectional cohorts of PD patients and healthy controls (HC): T-cell numbers as a robust and universal, well-described alteration in PD, $\mathrm{T}$-cells activation and expression of inflammatory genes.

\section{Methods}

\section{Study participants}

All experimental work with human samples was carried out in agreement with the Declaration of Helsinki and under the approval of the Ethics Committee of the University of Ulm, Germany ("Antrag Nr. 20/10"). All study participants provided informed written consent to participate in the study. PD patients and healthy controls were recruited through the Universitäts- und Rehabilitationskliniken Ulm (RKU). Age-matched healthy controls were recruited based on negative history of neurological disease. PD patients and healthy controls with a history of acute or chronic inflammatory or autoimmune disease or medication were excluded from the study. Disease severity was assessed by an experienced neurologist according to the Hoehn \& Yahr (HY) PD staging criteria [28]. Demographic and clinical characteristics including medication and selected comorbidities are summarized in Table 1.

\section{Flow cytometry}

Peripheral blood samples were collected with Li-Heparin Monovettes (Sarstedt) and processed within $3 \mathrm{~h}$. Red blood cells were eliminated by osmotic lysis with RBC lysis buffer as described before [2]. Leucocytes were then washed, re-suspended in FACS buffer (DPBS + 10\% FCS). Unspecific binding of antibodies to cell surface receptors was blocked with Fc Block (1:20, BioLegend) or human TruStain Fc Block (BioLegend) for $20 \mathrm{~min}$ at $4{ }^{\circ} \mathrm{C}$. Leucocytes were stained with antibodies specific for CD3 (1:50, BioLegend; UCHT1-PB), CD4 (1:100, BioLegend RPA-T4-PE), CD8 (1:100, BioLegend, SK1-APC), and CD69 (1:50, BioLegend; FN50-FITC) for 25 min at $4{ }^{\circ} \mathrm{C}$ in the dark. After washing, the stained cells were fixed for $20 \mathrm{~min}$ in $2 \%$ PFA, filtered through a $70 \mu \mathrm{M}$ cell-strainer and characterized by flow cytometry on a LSRII flow cytometer (BD) using a combination of unstained cells, internal negative population controls and single-color staining for color compensation. Therefore, isotypematched, host-matched monoclonal antibodies were used as negative control: mouse IgG2a, $\mathrm{\kappa}$ (BioLegend; MOPC173-PE-Cy7), mouse IgG1, к (BioLegend; MPOK-21-PB), mouse IgG1, $\mathrm{\kappa}$ (BioLegend; MOPC-21-PE), mouse IgG2a, $\kappa$ (eBioscience; P3.6.2.81-APC). Flow cytometry data was processed with FACS Diva ${ }^{\mathrm{TM}}$ software (BD).

\section{T-cell culture}

Blood samples were obtained by venipuncture and collected with K3-EDTA Monovettes (Sarstedt). Peripheral blood mononuclear cells (PBMCs) were enriched by density gradient centrifugation over Histopaque ${ }^{\circledR}-1077$ (Sigma-Aldrich) as previously described [29]. $\mathrm{CD}^{+} \mathrm{T}$ cells were enriched by magnetic-activated cell selection with magnetic-beads-coupled monoclonal antibodies to $\mathrm{CD} 3$ (Miltenyi Biotec). Purified $\mathrm{CD}^{+} \mathrm{T}$ cells were cultured in RPMI1640 cell culture medium (Gibco) supplemented with 10\% FCS (PAA) and 1\% penicillin/ streptomycin (PAA) at $37{ }^{\circ} \mathrm{C}, 5 \% \mathrm{CO}_{2}$. The purity of the isolated $\mathrm{T}$ cells was controlled by flow cytometry. For stimulation of $\mathrm{T}$ cells, cells were pelleted at $500 \mathrm{~g}$ for $5 \mathrm{~min}$ and re-suspended in T-cell activation media (Gibco; PB-MAX ${ }^{\mathrm{TM}}$ Karyotyping Medium) at a total density of $4 \times 10^{5}$ cells $/ \mathrm{mL}$. After $72 \mathrm{~h}$ of stimulation, the activation of the $\mathrm{T}$ cells was assayed by flow cytometry for CD69 expression.

\section{Inflammatory gene expression}

Expression of inflammatory genes was quantified on with the NanoString Inflammation Panel on an nCounter ${ }^{\circledR}$ analyzer with standard parameters according to the supplier's instructions. Total RNA was isolated from $\mathrm{T}$ cells purified by CD3 + magnetic selection as described above. Gene expression data was normalized to the geomean expression of six house-keeping genes and differential expression analyzed with DESeq2 [30].

RT-qPCR was performed as described before [2] with total mRNA isolated from purified $\mathrm{CD}^{+} \mathrm{T}$ cells. Gene expression of CXCL3 (5'-CCT GCC CTT ACC AGA GCT GAA A- $3^{\prime}$ and $5^{\prime}$-ATT AAG TCC TTT CCA GCT GTC CC-3'), CCR1 (5'-ATG CAA CTC CGT GCC AGA AGG-3' ${ }^{\prime}$ and $5^{\prime}$-AGG TCA GAA ATG GCC AGG TTC A-3') and CXCL2 (5'-CCA CTG TGA TAG AGG CTG AGG AA-3' and 5'-ATA CAT TTC CCT GCC GTC ACA TT-3') was quantified with the $2^{-\Delta \Delta \mathrm{Ct}}$ method [31] relative to the expression of $\mathrm{B} 2 \mathrm{M}$ ( $5^{\prime}$-AGA TGA GTA TGC CTG CCG TG- $3^{\prime}$ and $5^{\prime}$-GCG GCA TCT TCA AAC CTC CA-3'), TBP (5'-CCC ATG ACT CCC ATG ACC- $3^{\prime}$ and $5^{\prime}$-TTT ACA ACC AAG ATT CAC TGT GG-3') and RNU6 (5'-CTC GCT TCG GCA GCA CAT- $3^{\prime}$ and 5'-AAC GCT TCA CGA ATT TGC GT- $3^{\prime}$ ). The expression of each reference gene was controlled against the expression of the other two reference genes to exclude co-regulation of the reference and inflammatory genes. Genomic DNA and PCR artifacts were excluded with NTC and NRT controls and by optimization of primer design. 


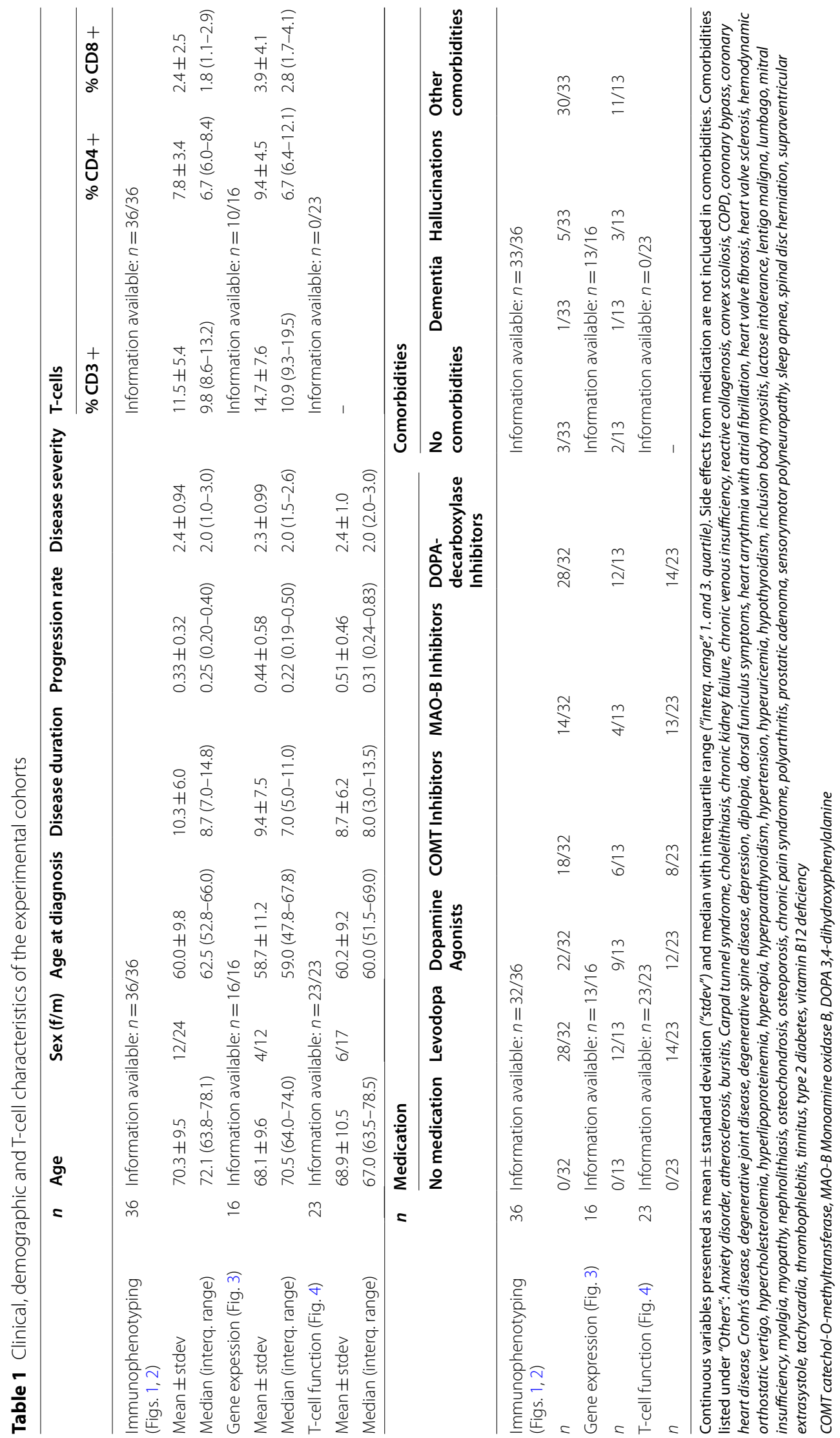




\section{Data analysis}

Statistical analyses were carried out with R 4.0.3 (R Core Team). Gaussian distribution was tested with D'Agostino and Pearson omnibus normality test, Shapiro-Wilk normality test and Kolmogorov-Smirnov normality test. Statistical significance between distributions of two groups was tested with Mann-Whitney $U$ test; correlation with Spearman's correlation and odd ratios with Chi-square test and Fisher's exact test. Multiple testing was controlled with Bonferroni. Interaction of covariates on dependable variables was tested with two-way ANOVA. Density bandwidth estimation for the stratification of PD patients according to clinical parameters was performed with the Sheather and Jones method to avoid underand oversmoothing [32]. Hierarchical clustering of gene expression data was performed with average linkage and Euclidean distance. Differential gene expression was analyzed with DESeq2 with standard parameters [30]. Statistical significance of differential expression data was corrected for multiple testing with FDR [33]. Weighted gene co-expression network analysis was performed with the WGCNA R package [34, 35]. Flow cytometry data were analyzed with FACS Diva 8.0.1 software (BD).

\section{Results}

\section{Decrease of total $\mathrm{CD}^{+} \mathrm{T}$ cells in PD is associated with disease severity}

To investigate how clinical parameters of PD relate to the changes observed in the numbers of $\mathrm{T}$ cells in $\mathrm{PD}$, we investigated the relative abundance of total $\mathrm{CD}^{+} \mathrm{T}$ cells, as well as the subpopulations of $\mathrm{CD}^{+}{ }^{+} \mathrm{CD} 4^{+}$and $\mathrm{CD}^{+} \mathrm{CD}^{+} \mathrm{T}$ cells in a cross-sectional cohort of $36 \mathrm{PD}$ patients (mean age $70.3 \pm 9.5 ; \mathrm{f} / \mathrm{m}=12 / 24$; mean $\mathrm{H} \& \mathrm{Y}$ $2.4 \pm 0.94)$ and 20 age-matched $(p>0.32)$ healthy controls (mean age $67.8 \pm 8.0 ; \mathrm{f} / \mathrm{m}=13 / 7$ ) (Fig. 1A). We observed a statistically significant decrease of $\mathrm{CD}^{+} \mathrm{T}$ cells (as $\%$ of all leucocytes) in PD patients (Fig. 1B), which was independent of differences in the age (Fig. 1C, two-way

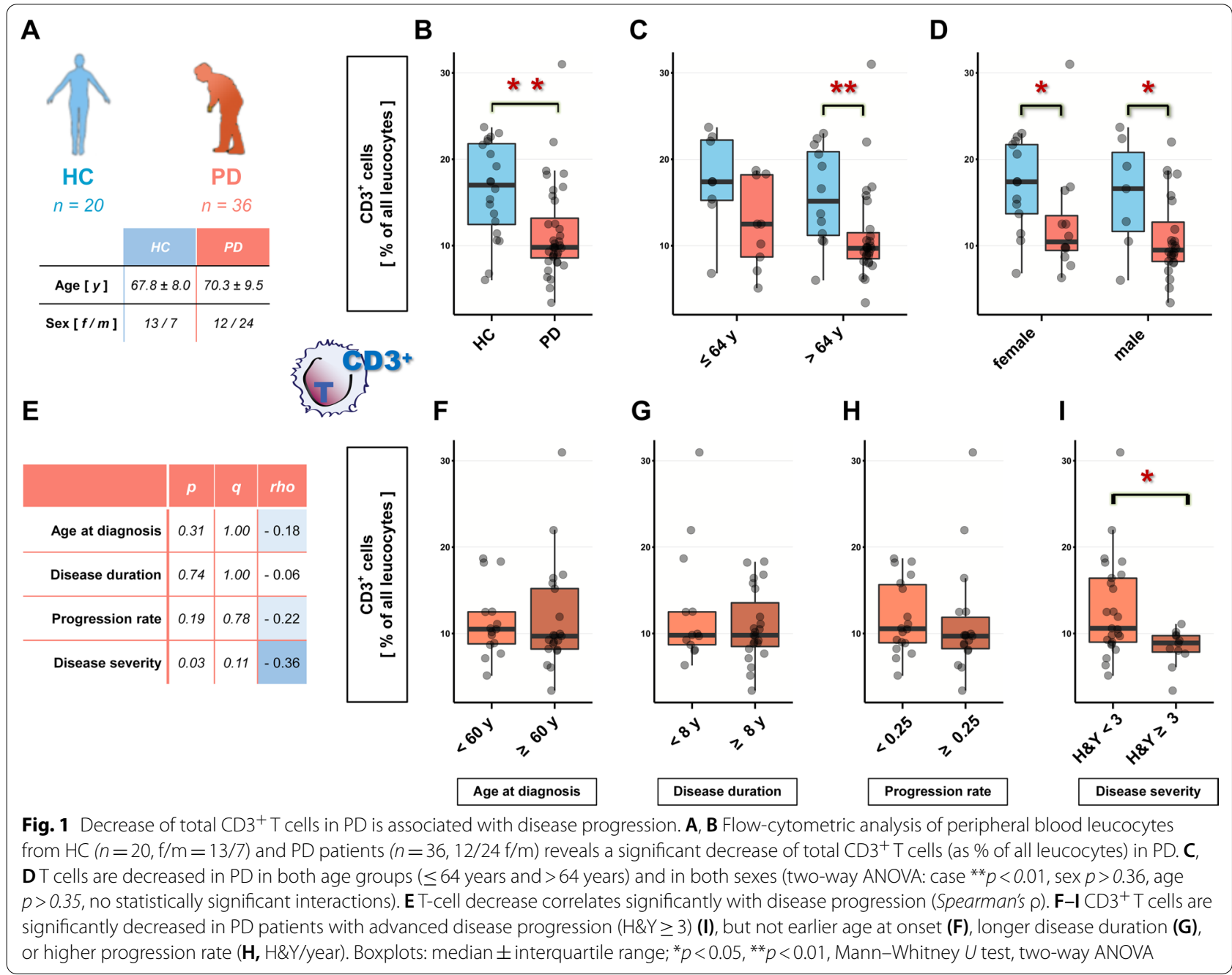


ANOVA $* * 0.01$ for HC vs. PD, $p>0.35$ for $\leq 64$ years vs. $>64$ years, $p>0.86$ for interaction) or sex of $\mathrm{PD}$ patients and healthy controls (Fig. 1D, two-way ANOVA $* * p<0.01$ for HC vs. PD, $p>0.36$ for $\mathrm{f}$ vs. $\mathrm{m}, p>0.78$ for interaction). We then investigated the association of $\mathrm{CD}^{+}$cell decrease with age at initial diagnosis, disease duration, disease progression rate and disease severity assessed by H\&Y score. Notably, only disease severity correlated with the observed decrease of $\mathrm{CD}^{+} \mathrm{T}$ cells (Fig. 1E, " $p<0.05, q<0.16$, Spearman's $\rho=-0.36$ ). Stratification by clinical parameters revealed a statistically significant difference in $\mathrm{CD}^{+} \mathrm{T}$ cells numbers between patients with relatively earlier disease $(H \& Y<3)$ and relatively advanced disease (H\&Y $\geq 3$ ) (Fig. $\left.1 \mathrm{I},{ }^{*} p<0.05\right)$, but not between PD patients stratified by age at diagnosis $(<60$ years vs. $\geq 60$ years, Fig. $1 F)$, disease duration since initial diagnosis $(<8$ years vs. $\geq 8$ years $)$ and disease progression rate (assessed by $\mathrm{H} \& \mathrm{Y}$ stage increase per year since initial diagnosis, $<0.25$ vs. $\geq 0.25$, Fig. 1G).
Furthermore, a multivariate analysis of variation with the discretely stratified clinical traits confirmed that only disease severity has a significant effect on the number of $\mathrm{CD}^{+} \mathrm{T}$ cells, with no detectable interaction between any combination of the clinical traits.

Next, we investigated whether the decrease of $\mathrm{CD}^{+} \mathrm{T}$ cells in $\mathrm{PD}$ patients results from changes in the abundance of the T-cell subpopulations $\mathrm{CD}^{+} \mathrm{CD}^{+}$or $\mathrm{CD}^{+} \mathrm{CD}^{+}$ $\mathrm{T}$ cells, and whether the abundance of these cell types also associates with clinical parameters of the disease. We found that both $\mathrm{CD}^{+}{ }^{+} \mathrm{CD} 4^{+}$and $\mathrm{CD}^{+}{ }^{+} \mathrm{CD} 8^{+} \mathrm{T}$ cells were significantly decreased in PD patients (Fig. 2A, E). However, $\mathrm{CD}^{+}{ }^{+} \mathrm{CD} 8^{+} \mathrm{T}$ cells showed a stronger decrease than $\mathrm{CD}^{+} \mathrm{CD}^{+}{ }^{+} \mathrm{T}$ cells (fold change of medians $\mathrm{CD} 4^{+}$: $0.68, \mathrm{CD}^{+}: 0.40$ ), resulting in an increase of the relative percentage of $\mathrm{CD}^{+} \mathrm{CD}^{+} \mathrm{T}$ cells and the $\mathrm{CD} 4^{+}: \mathrm{CD} 8^{+}$ cell ratio in PD patients. The decrease of each cell type alone was not significantly associated with any clinical trait, but showed a trend for association with disease

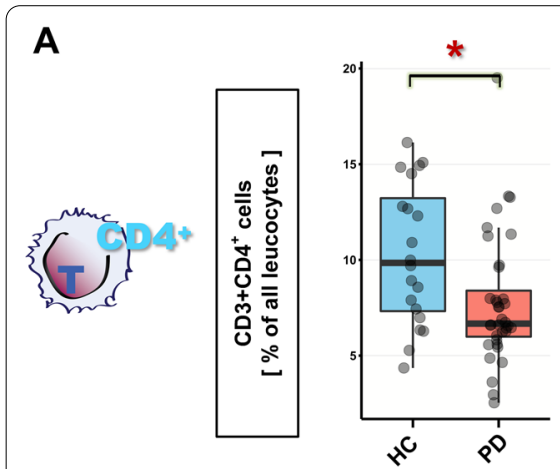

B

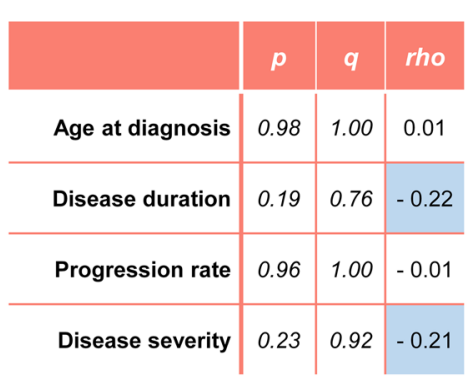

C

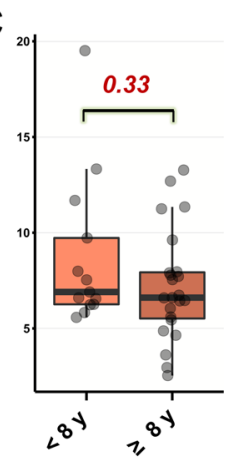

E

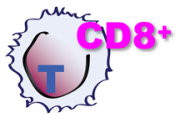

$\mathbf{F}$

G
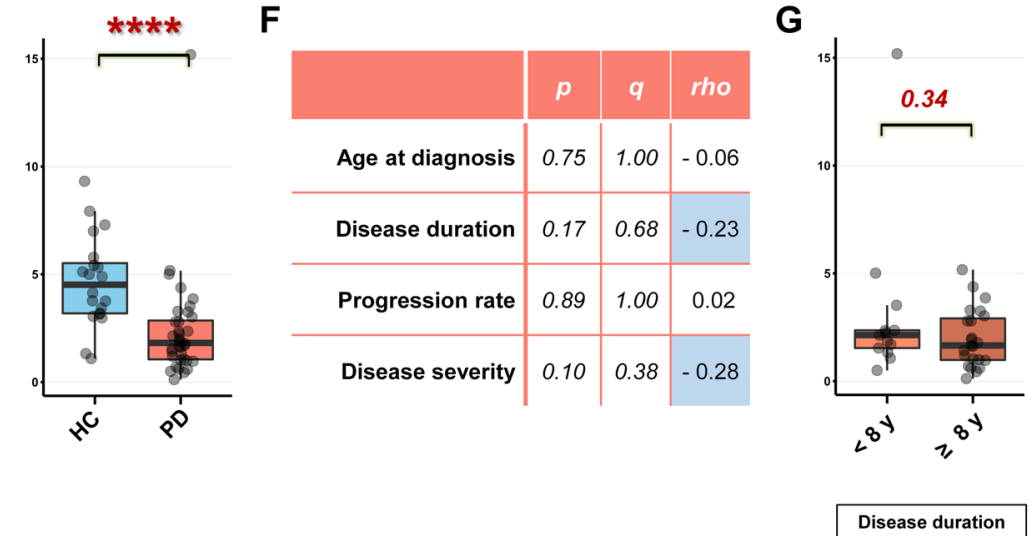

D

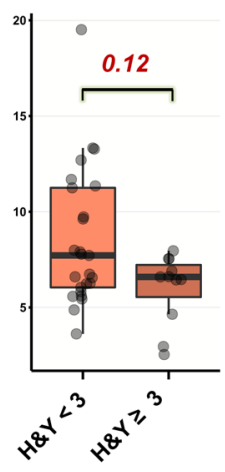

H

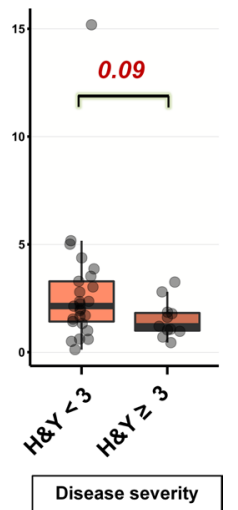

Fig. $2 \mathrm{CD}^{+}$and $\mathrm{CD} 8^{+}$T cells are decreased in PD. A CD3 ${ }^{+} \mathrm{CD} 4^{+} \mathrm{T}$ cells are significantly decreased in PD patients (as \% of all leucocytes, two-way ANOVA: case ${ }^{*} p<0.05$, sex $p>0.36$, age $p>0.41$, no statistically significant interactions). B Correlation of $\mathrm{CD}^{+} \mathrm{CD}^{+}$cell numbers with PD clinical traits (Spearman's $\rho$ ). C, D CD3 ${ }^{+} \mathrm{CD} 4^{+}$cell numbers in PD patients stratified by disease duration $(\mathbf{C})$ and disease progression $(\mathbf{D})$. $\mathbf{E} C D 3^{+} \mathrm{CD} 8^{+} \mathrm{T}$ cells are significantly decreased in PD patients (as \% of all leucocytes, two-way ANOVA: case ${ }^{* *} p<0.01$, sex $p>0.41$ age $p>0.62$, no statistically significant interactions). $\mathbf{F}$ Correlation of $\mathrm{CD}^{+} \mathrm{CD}^{+}$cell numbers with PD clinical traits (Spearman's $\rho$ ). $\mathbf{G}, \mathbf{H} \mathrm{CD} 3^{+} \mathrm{CD} 8^{+}$cell numbers in PD patients stratified by disease duration $(\boldsymbol{G})$ and disease progression $(\mathbf{H})$. Boxplots: median \pm interquartile range; ${ }^{*} p<0.05,{ }^{* * * *} p<0.0001$, Mann-Whitney $U$ test, two-way ANOVA 
severity (Fig. 2B-D, F-H; $p<0.13\left(\mathrm{CD}^{+} \mathrm{CD}^{+}\right), p<0.09$ $\left.\left(\mathrm{CD}^{+} \mathrm{CD}^{+}\right)\right)$. We found no significant correlation of the absolute or relative numbers of $\mathrm{CD} 4+$ and $\mathrm{CD} 8+\mathrm{T}$ cells with any clinical parameter of PD.

\section{Expression of inflammatory genes and activation by PHA in T cells from PD patients are associated with disease severity}

The association of inflammation with PD progression is well-documented. Therefore, to further characterize the dysregulation of $\mathrm{T}$ cells in PD patients and its association to clinical parameters of the disease, we purified $\mathrm{CD}^{+} \mathrm{T}$ cells by magnetic-activated cell sorting in a cross-sectional cohort of PD patients $(n=16$, mean age $68.1 \pm 9.6 ; \mathrm{f} / \mathrm{m}=4 / 12)$ and healthy controls $(n=14$, mean age $64.1 \pm 14.5 ; \mathrm{f} / \mathrm{m}=10 / 4)$ and quantified the expression of 249 inflammatory genes with the NanoString Inflammation panel expression assay (Fig. 3A). We observed that the total expression of all 249 inflammatory genes was slightly, but not statistically significantly increased in PD patients (Fig. 3A, $p<0.25$ ). Unsupervised hierarchical clustering demonstrated that the expression levels of all 249 quantified inflammatory genes did not robustly differentiate between PD patients and healthy controls, although some sub-clusters were visible (Fig. 3B). Differential expression analysis identified one gene which was significantly down-regulated and eight genes which were significantly up-regulated in PD $\mathrm{T}$ cells (Fig. 3C; fc $</>0.5, q<0.05)$, with an enrichment of cytokines and chemokines (IL6, IL8, CXCL2, CXCL3, CXCL5). Due to the uneven distribution of male and female volunteers between the PD patients and healthy controls groups, we controlled the expression of all nine differentially expressed genes for an effect of sex or age of the volunteers with multivariate two-way ANOVA. None of the nine differential genes' expression was affected by sex or age of the study participants and no interaction between case and age/sex was observed at $p<0.05$. The expression of these genes was highly variable in the PD patients group (Fig. 3D). Furthermore, we could validate the differential expression of two of the three top differentially expressed genes in an independent validation cohort by RT-qPCR (Fig. 3E, HC/PD $n=12 / 12$; HC: mean age $64.7 \pm 7.9, \mathrm{f} / \mathrm{m}=5 / 7$; PD: mean age $69.1 \pm 5.8, \mathrm{f} / \mathrm{m}=5 / 7$, mean disease severity: $2.2 \pm 0.9 \mathrm{HY}$, mean disease duration: $7.5 \pm 5.4$ years). Next, to investigate whether PD clinical traits are associated with the expression of inflammatory genes in $\mathrm{T}$ cells, we performed a weighted gene co-expression network analysis (WGCNA), clustering the 249 inflammatory genes into six modules of similar expression pattern across all PD patients and healthy controls ("Modules A-F"). Correlation of the module expression scores with clinical parameters revealed that the expression of two modules ("E" and " $\mathrm{F}$ ") was associated with disease duration, while the expression of one module ("B") was significantly, positively correlated to disease severity and progression rate (Fig. 3F). To gain further mechanistic insight, we analyzed the functional enrichment of Gene Ontology (GO) terms of the genes in modules "B", "E" and "F" against the full list of 249 quantified inflammatory genes (Fig. 3G). We found that genes involved in the regulation of gliogenesis and acute inflammatory response were significantly enriched $(* * 0<0.01, q>0.05)$ in module "B", which was associated with disease severity.

To investigate the functional relevance of this finding, we next mimicked acute inflammatory response by stimulating $\mathrm{T}$ cells with PHA and measured T-cell activation with flow cytometry using CD69 staining in an independent cohort of 23 PD (mean age $68.9 \pm 10.5 ; \mathrm{f} / \mathrm{m}=6 / 17$ ) patients and 14 healthy controls (mean age $67.3 \pm 12.2$; $\mathrm{f} / \mathrm{m}=6 / 8$ ) (Fig. 4A). As with gene expression, we found only a slight, statistically non-significant increase of T-cell activation by PHA in PD patients' T cells (Fig. 4B, $p>0.32$ ). Activation of $\mathrm{T}$ cells was not significantly correlated to any clinical trait; however, stratification into discrete clinical traits revealed a significantly increased activation of $\mathrm{T}$ cells in PD patients with more advanced disease (Fig. 4D, $p<0.05$, no statistically significant bias by age or sex). T-cell activation did not significantly differ in all other discretely stratified clinical traits.

\section{Discussion}

In the present work, we investigated the association of the clinical parameters of PD age at diagnosis, disease duration, disease progression rate and disease severity as well as age and sex of the probands with changes of T-cell numbers, expression of inflammatory genes in $\mathrm{T}$ cells, and activation of $\mathrm{T}$ cells by PHA. Through thorough statistical analysis, we demonstrate that disease severity is the only clinical trait correlating with T-cell pathology independently from age, sex and other clinical traits of PD. Our data suggests that total $\mathrm{CD}^{+}$numbers and expression of inflammatory markers are robust markers of PD severity and warrants further validation with standardized procedures in large, multi-center approaches.

Standardized T-cell counts and phenotyping are an easily accessible, automatable readout which can be routinely utilized at relative low costs to longitudinally track disease progression in controlled settings, such as clinical trials for disease-modifying therapies. However, determining T-cell features suffers from lack of specificity; thus, it is necessary to fully understand common confounding factors and ideally to complement it by an additional readout that increases specificity. We address 


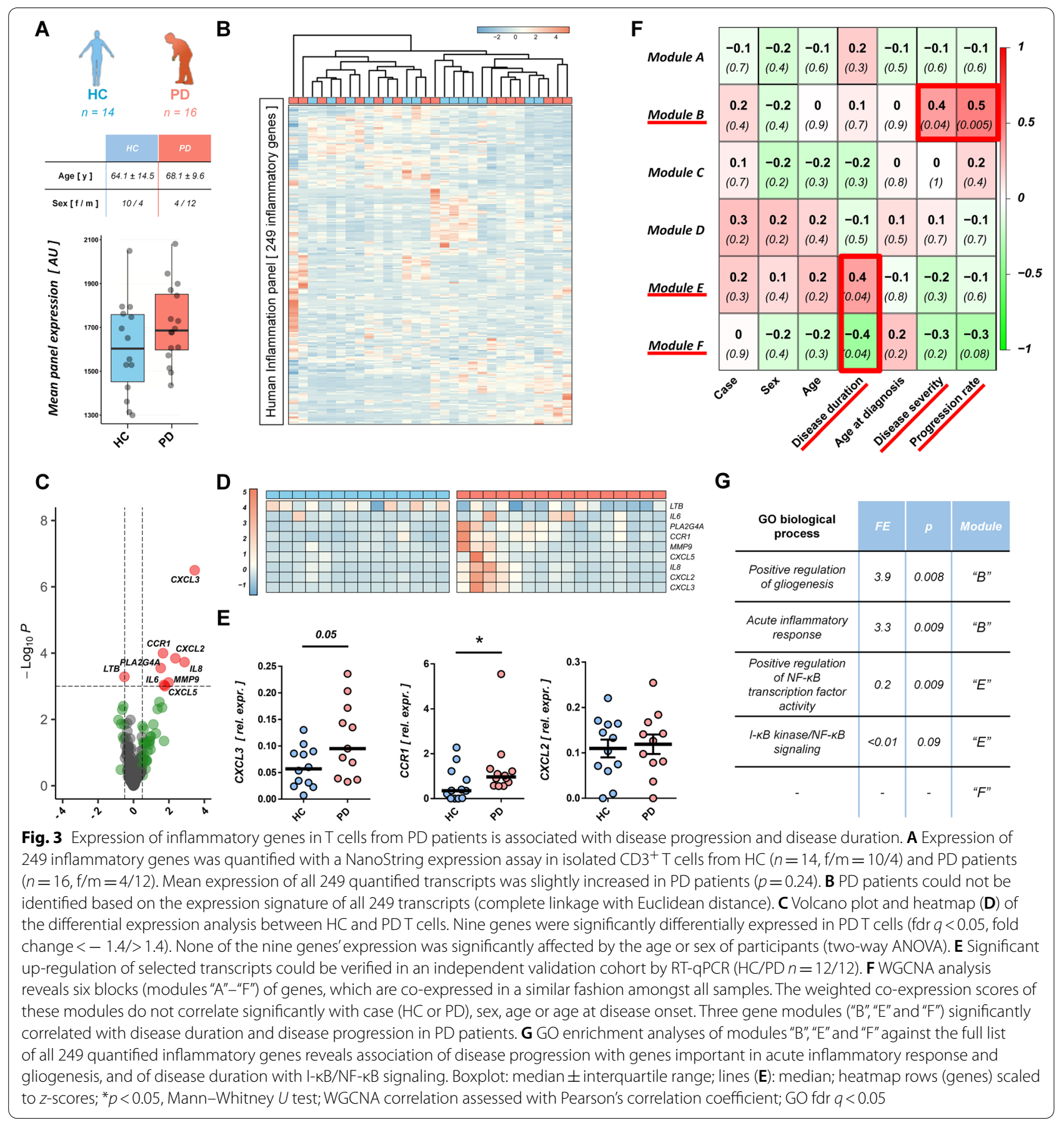

this paradigm by demonstrating that both $\mathrm{CD}^{+}$cell numbers and inflammatory gene expression in $\mathrm{T}$ cells correlate mainly with disease severity. The main limitation of our study is the relatively low cohort number, limiting the statistical power and thus the certainty with which correlation with other clinical parameters can be ruled out. However, the cohort size in this study is sufficient to demonstrate that disease severity is the main clinical trait that defines the measured T-cell features. Indeed, several other studies have found that the relative abundance of subsets of $\mathrm{T}$ cells correlates with disease severity: CD4 + T cells [15, 18], Th1/Th2 T cells [21], Th17/Treg cells $[21,26]$. The relative reduction of a leucocyte subset can result from its own decrease or from an increase of the other subsets in the superset. Therefore, it is important to base all analyses on an absolute 


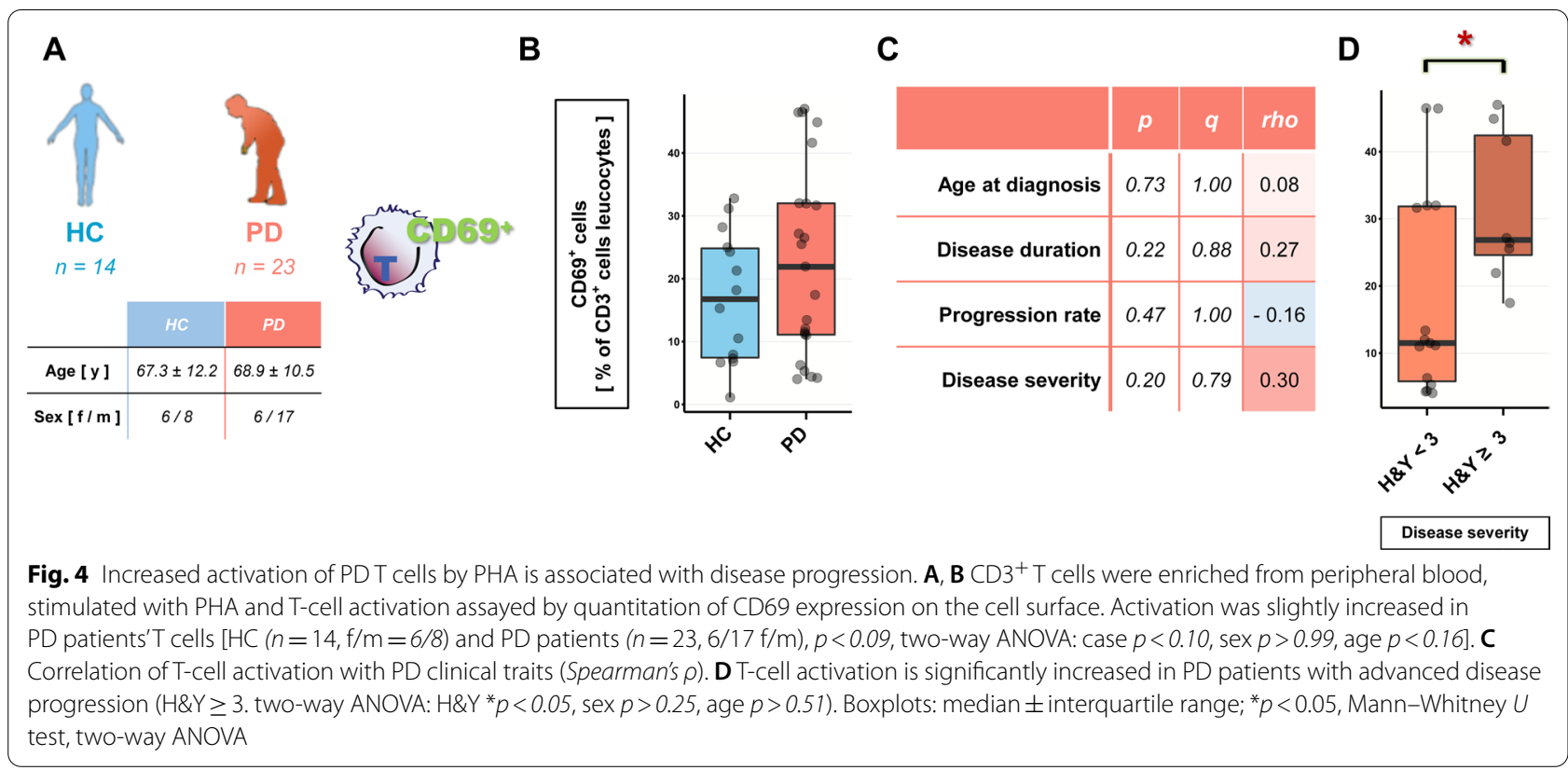

leucocyte or lymphocyte count. In our study, we chose the total number of $\mathrm{CD}^{+} \mathrm{T}$ cells as a readout, which has been verified numerous times previously by absolute counts $[14-16,18]$. Further factors that could not be taken in consideration in this study, but should be included in future large-scale analyses, concern diurnal variation in leucocyte subsets, bias by comorbidities, CMV serology and effect of medication. The latter two have been partially addressed in previous studies, which found no significant bias by these factors [5, 14]. One further study demonstrated a clear effect specifically of levodopa on T-cell numbers [27], and it is also known that dopamine has a strong effect on $\mathrm{T}$ cells. Thus, levodopa medication may induce or enhance the T-cell decrease in PD patients. However, it is unlikely that levodopa medication confounds the association of T-cell decrease with disease severity, since the majority $(88 \%)$ of the PD patients in our immunophenotyping study were treated with levodopa.

Interestingly, recent breakthrough studies have demonstrated that alpha-synuclein-specific $\mathrm{T}$ cells are increased in PD patients, probably in association with risk haplotypes of HLA, and suggest an autoimmune involvement of $\mathrm{T}$ cells in PD $[8,11]$. A causal role of alpha-synuclein reactive $\mathrm{T}$ cells was recently reinforced also by an animal model study [36]. The occurrence of alpha-synuclein-reactive $\mathrm{T}$ cells was increased years before motor onset in a case study and their frequency was highest around and shortly after motor onset in a larger cross-sectional cohort of PD patients [11]. After motor onset, the T-cell response to alpha-synuclein declined with increasing disease duration. By contrast, our data suggests a progressing generalized T-cell dysfunction with ongoing disease, probably reflecting the combined effect of ongoing inflammation, medication and lifestyle change. Thus, specific T-cell reactivity to alpha-synuclein will be more informative before and around disease onset, e.g., in prospective clinical studies, while generalized T-cell dysfunction will be more appropriate for tracking disease progress in diseasemodifying trials.

To our knowledge, our study is the first to address the association of T-cell gene expression and clinical parameters of PD. While the sample size of the PD group was too small for reliable correlation of single genes with disease parameters, statistical power was sufficient for the blockwise correlation of gene expression with disease parameters. Indeed, we found a correlation of disease severity with modules of inflammatory gene expression, which could be validated also on a functional level. Further studies with larger numbers of PD patients are warranted to select optimal gene targets for expression analysis to complement T-cell counts for increased specificity of disease severity tracking.

\section{Abbreviations}

PD: Parkinson's Disease; CNS: Central nervous system; HC: Healthy control; HY: Hoehn \& Yahr stage; PBMC: Peripheral blood mononuclear cell; GO: Gene Ontology; RT-gPCR: Quantitative reverse-transcription PCR; PCR: Polymerase chain reaction; ANOVA: Analysis of variance; FDR: False discovery rate; PHA: Phytohemagglutinin. 


\section{Acknowledgements}

We thank all volunteers who participated in the study. We thank R. Bück for the excellent technical assistance and S. Milde, L. Bayer and M. Pflüger for collecting blood samples.

\section{Author's contributions}

DB performed the experiments, DB, VG and WPR analyzed the data, ACL, JK, $J H W$ and KMD provided intellectual input. VG and KMD wrote the manuscript. All authors read and approved the final manuscript.

\section{Funding}

Open Access funding enabled and organized by Projekt DEAL. This work was supported by the Deutsche Forschungsgemeinschaft (DFG) Emmy Noether Research Group DA 1657/2-1 (KMD, VG) and GRK 1789 (CEMMA, DB).

\section{Availability of data and materials}

The data sets analysed during the current study are available from the corresponding author on reasonable request.

\section{Declarations}

\section{Ethics approval and consent to participate}

All experimental work with human samples was carried out in agreement with the Declaration of Helsinki and under the approval of the Ethics Committee of the University of Ulm, Germany. All study participants provided informed written consent to participate in the study.

\section{Consent for publication}

Not applicable.

\section{Competing interests}

The authors declare that they have no conflict of interest.

\author{
Author details \\ ${ }^{1}$ Neurology, University Clinic, University of Ulm, Albert-Einstein-Allee 11, \\ 89081 Ulm, Germany. ${ }^{2}$ German Center for Neurodegenerative Diseases \\ (DZNE), Ulm, Germany. ${ }^{3}$ Division for Neurodegenerative Diseases, Neurology \\ Department, University Medicine Mannheim, Heidelberg University, Man- \\ nheim, Germany.
}

Received: 9 July 2021 Accepted: 13 October 2021

Published online: 30 October 2021

\section{References}

1. Brochard V, Combadiere B, Prigent A, Laouar Y, Perrin A, Beray-Berthat V, Bonduelle O, Alvarez-Fischer D, Callebert J, Launay JM, et al. Infiltration of CD4+ lymphocytes into the brain contributes to neurodegeneration in a mouse model of Parkinson disease. J Clin Invest. 2009;119:182-92.

2. Grozdanov V, Bliederhaeuser C, Ruf WP, Roth V, Fundel-Clemens K, Zondler L, Brenner D, Martin-Villalba A, Hengerer B, Kassubek J, et al. Inflammatory dysregulation of blood monocytes in Parkinson's disease patients. Acta Neuropathol 2014; 128:651-663.

3. Harms AS, Ferreira SA, Romero-Ramos M. Periphery and brain, innate and adaptive immunity in Parkinson's disease. Acta Neuropathol. 2021;141:527-45.

4. Schonhoff AM, Williams GP, Wallen ZD, Standaert DG, Harms AS. Innate and adaptive immune responses in Parkinson's disease. Prog Brain Res. 2020;252:169-216.

5. Williams-Gray CH, Wijeyekoon RS, Scott KM, Hayat S, Barker RA, Jones JL. Abnormalities of age-related T cell senescence in Parkinson's disease. J Neuroinflammation. 2018;15:166.

6. Calopa M, Bas J, Callen A, Mestre M. Apoptosis of peripheral blood lymphocytes in Parkinson patients. Neurobiol Dis. 2010;38:1-7.

7. Scott KM, Kouli A, Yeoh SL, Clatworthy MR, Williams-Gray CH. A systematic review and meta-analysis of alpha synuclein auto-antibodies in Parkinson's Disease. Front Neurol. 2018;9:815.

8. Sulzer D, Alcalay RN, Garretti F, Cote L, Kanter E, Agin-Liebes J, Liong C, McMurtrey C, Hildebrand WH, Mao X, et al. T cells from patients with Parkinson's disease recognize alpha-synuclein peptides. Nature. 2017;546:656-61.

9. Saiki M, Baker A, Williams-Gray CH, Foltynie T, Goodman RS, Taylor CJ, Compston DA, Barker RA, Sawcer SJ, Goris A. Association of the human leucocyte antigen region with susceptibility to Parkinson's disease. J Neurol Neurosurg Psychiatry. 2010;81:890-1.

10. Nalls MA, Pankratz N, Lill CM, Do CB, Hernandez DG, Saad M, DeStefano AL, Kara E, Bras J, Sharma M, et al. Large-scale meta-analysis of genomewide association data identifies six new risk loci for Parkinson's disease. Nat Genet. 2014;46:989-93.

11. Lindestam Arlehamn CS, Dhanwani R, Pham J, Kuan R, Frazier A, Rezende Dutra J, Phillips E, Mallal S, Roederer M, Marder KS, et al. alpha-Synucleinspecific T cell reactivity is associated with preclinical and early Parkinson's disease. Nat Commun. 1875;2020:11.

12. Fiszer U, Mix E, Fredrikson S, Kostulas V, Link H. Parkinson's disease and immunological abnormalities: increase of HLA-DR expression on monocytes in cerebrospinal fluid and of CD45RO+ T cells in peripheral blood. Acta Neurol Scand. 1994;90:160-6.

13. Fiszer U, Mix E, Fredrikson S, Kostulas V, Olsson T, Link H. gamma delta+ T cells are increased in patients with Parkinson's disease. J Neurol Sci. 1994;121:39-45.

14. Bas J, Calopa M, Mestre M, Mollevi DG, Cutillas B, Ambrosio S, Buendia E. Lymphocyte populations in Parkinson's disease and in rat models of parkinsonism. J Neuroimmunol. 2001;113:146-52.

15. Hisanaga K, Asagi M, Itoyama Y, Iwasaki Y. Increase in peripheral CD4 bright+ CD8 dull+ T cells in Parkinson disease. Arch Neurol. 2001;58:1580-3.

16. Baba Y, Kuroiwa A, Uitti RJ, Wszolek ZK, Yamada T. Alterations of T-lymphocyte populations in Parkinson disease. Parkinsonism Relat Disord. 2005; 11:493-8.

17. Gruden MA, Sewell RD, Yanamandra K, Davidova TV, Kucheryanu VG, Bocharov EV, Bocharova OA, PolyschukV, Sherstnev VV, Morozova-Roche LA. Immunoprotection against toxic biomarkers is retained during Parkinson's disease progression. J Neuroimmunol. 2011;233:221-7.

18. Saunders JA, Estes KA, Kosloski LM, Allen HE, Dempsey KM, Torres-Russotto DR, Meza JL, Santamaria PM, Bertoni JM, Murman DL, et al. CD4+ regulatory and effector/memory $T$ cell subsets profile motor dysfunction in Parkinson's disease. J Neuroimmune Pharmacol. 2012;7:927-38.

19. Stevens CH, Rowe D, Morel-Kopp MC, Orr C, Russell T, Ranola M, Ward C, Halliday GM. Reduced T helper and B lymphocytes in Parkinson's disease. J Neuroimmunol. 2012;252:95-9.

20. Chen S, Liu Y, Niu Y, Xu Y, Zhou Q, Xu X, Wang J, Yu M. Increased abundance of myeloid-derived suppressor cells and Th17 cells in peripheral blood of newly-diagnosed Parkinson's disease patients. Neurosci Lett. 2017;648:21-5.

21. Chen Y, Qi B, Xu W, Ma B, Li L, Chen Q, Qian W, Liu X, Qu H. Clinical correlation of peripheral $C D 4+$ cell subsets, their imbalance and Parkinson's disease. Mol Med Rep. 2015;12:6105-11.

22. Chen Y, Yu M, Liu X, Qu H, Chen Q, Qian W, Wei D, Xu W, Ma B, Wu W. Clinical characteristics and peripheral T cell subsets in Parkinson's disease patients with constipation. Int J Clin Exp Pathol. 2015;8:2495-504.

23. Sommer A, Marxreiter F, Krach F, Fadler T, Grosch J, Maroni M, Graef D, Eberhardt E, Riemenschneider MJ, Yeo GW, et al. Th17 lymphocytes induce neuronal cell death in a human iPSC-based model of Parkinson's Disease. Cell Stem Cell. 2018;23:123-31.

24. Kustrimovic N, Comi C, Magistrelli L, Rasini E, Legnaro M, Bombelli R, Aleksic I, Blandini F, Minafra B, Riboldazzi G, et al. Parkinson's disease patients have a complex phenotypic and functional Th1 bias: cross-sectional studies of CD4+ Th1/Th2/T17 and Treg in drug-naive and drug-treated patients. J Neuroinflammation. 2018;15:205.

25. Alvarez-Luquin DD, Arce-Sillas A, Leyva-Hernandez J, Sevilla-Reyes E, Boll MC, Montes-Moratilla E, Vivas-Almazan V, Perez-Correa C, RodriguezOrtiz U, Espinoza-Cardenas R, et al. Regulatory impairment in untreated Parkinson's disease is not restricted to Tregs: other regulatory populations are also involved. J Neuroinflammation. 2019;16:212.

26. Thome AD, Atassi F, Wang J, Faridar A, Zhao W, Thonhoff JR, Beers DR, Lai EC, Appel SH. Ex vivo expansion of dysfunctional regulatory T lymphocytes restores suppressive function in Parkinson's disease. NPJ Parkinsons Dis. $2021 ; 7: 41$. 
27. Hu ZX, Song WN, Lu XD, Zhou ML, Shao JH. Peripheral T lymphocyte immunity and I-dopamine in patients with Parkinson's disease. J Biol Regul Homeost Agents. 2018;32:687-91.

28. Hoehn MM, Yahr MD. Parkinsonism: onset, progression and mortality. Neurology. 1967;17:427-42.

29. Grozdanov V, Bousset L, Hoffmeister M, Bliederhaeuser C, Meier C, Madiona K, Pieri L, Kiechle M, McLean PJ, Kassubek J, et al. Increased immune activation by pathologic alpha-synuclein in Parkinson's Disease. Ann Neurol. 2019;86:593-606.

30. Love MI, Huber W, Anders S. Moderated estimation of fold change and dispersion for RNA-seq data with DESeq2. Genome Biol. 2014;15:550.

31. Livak KJ, Schmittgen TD. Analysis of relative gene expression data using real-time quantitative PCR and the 2(-Delta Delta C(T)) Method. Methods. 2001;25:402-8.

32. Sheather SJ, Jones MC. A reliable data-based bandwidth selection method for kernel density estimation. J Roy Stat Soc: Ser B (Methodol). 1991;53:683-90.
33. Benjamini Y, Hochberg Y. Controlling the false discovery rate-a practical and powerful approach to multiple testing. J Roy Stat Soc Ser B-Methodol. 1995:57:289-300.

34. Langfelder P, Horvath S. WGCNA: an R package for weighted correlation network analysis. BMC Bioinformatics. 2008;9:559.

35. Langfelder P, Horvath S. Fast R functions for robust correlations and hierarchical clustering. J Stat Softw 2012; 46.

36. Williams GP, Schonhoff AM, Jurkuvenaite A, Gallups NJ, Standaert DG, Harms AS. CD4 T cells mediate brain inflammation and neurodegeneration in a mouse model of Parkinson's disease. Brain. 2021;144:2047-59.

\section{Publisher's Note}

Springer Nature remains neutral with regard to jurisdictional claims in published maps and institutional affiliations.
Ready to submit your research? Choose BMC and benefit from:

- fast, convenient online submission

- thorough peer review by experienced researchers in your field

- rapid publication on acceptance

- support for research data, including large and complex data types

- gold Open Access which fosters wider collaboration and increased citations

- maximum visibility for your research: over $100 \mathrm{M}$ website views per year

At BMC, research is always in progress.

Learn more biomedcentral.com/submissions 